\title{
The Correlation Between Students' Vocabulary Mastery and Students' Speaking Skill
}

\author{
$1^{\text {st }}$ Obay Jambari \\ English Study Program \\ STKIP Setiabudhi Rangkasbitung \\ Indonesia \\ obayzam@gmail.com \\ $4^{\text {th }}$ Arief Styo Nugroho \\ STKIP Setiabudhi Rangkasbitung \\ Indonesia \\ $7^{\text {th }}$ Habib Cahyono \\ STKIP Setiabudhi Rangkasbitung \\ Indonesia
}

\author{
$2^{\text {nd }}$ Rina Khaerina \\ SMK Setiabudhi Rangkasbitung \\ Indonesia \\ echasetia14@gmail.com
}

$5^{\text {th }}$ Berita Mamabarasi Nehe

STKIP Setiabudhi Rangkasbitung Indonesia

\author{
$3^{\text {rd }}$ Puji Siswanto \\ STKIP Setiabudhi Rangkasbitung \\ Indonesia
}

\author{
$6^{\text {th }}$ Nunung Nurhayati \\ STKIP Setiabudhi Rangkasbitung \\ Indonesia
}

\begin{abstract}
Vocabulary is an important element of any language since its roles affect on language performance of the users. The present study investigates the correlation between students' vocabulary and their speaking skills at the secondgrade students of MTs Mursyidatul Jannah Pandeglang. A descriptive quantitative method was employed in the study. The participants of the study are the second-grade students which consist of thirty students. vocabulary test and speaking test were administered to attain the data of students' vocabulary mastery and their speaking skills. Having collected the data, the writer usedthe Pearson Product Moment Correlation in analyzing the data. Based on the data analysis, the study reveals that there is good correlation between the students' vocabulary mastery and their speaking skills. Further, the result of hypothesis testing shows that there is a positive correlation between the students' vocabulary mastery and students' speaking skills. The means score of the students' vocabulary mastery is 6,5 and theirspeaking skillsis 6,7 . The $r$-value is 0,54 while the $r$-table is 0,46ata significance level of $1 \%$. From the results decides that $r$ - obtained $(0,54)$ is higher than $r$ - table $(0.46)$. It meant the $r$-value is significant.
\end{abstract}

Keywords-Vocabulary, Students, Mastery, Speaking Skill

\section{INTRODUCTION}

Language as a meansof communication seems to have played an important role in human life. Both Language and human beings can not be separated. Human perceptively can run well because they use language to communicate something one another. Through the language, people gain a better insight into human relations; they use the language to express their ideas and thoughts. Meanwhile language itself can survive and develop because people use it and teach to other people. Whoever, whenever and wherever they are, language always accompanies them. Even when it is silent, basically he still uses language it is a means used to form thought and feeling, will, and activity.
English has an important role in the world. The different growth of languages makes it the most popular among the other international languages. Nowadays, there is no part of the world affairs know nothing about English. International affairs such as education, economics, sport, science, medicine and security, always involve English as a medium. Besides, it must realize that most scientific books are written in English. Accordingly to be able to comprehend the books for getting knowledge, one must have mastery in English and so must the Indonesian students.

In Indonesia, English is themost foreign language learning at schools. With this position, it does not have a social function as wide as a second language. English in the academic field is taught as a subject matter. By learning English the learners are hoped to be able to communicate about anything in English. To achieve the communicative function, we need general knowledge and skill of English and language components. There are four language skills involved in mastering English that the learners should have,they are listening, reading, speaking, and writing. So, it needs a curriculum which arranges the language skills, Competence Based Curriculum tries to develop and achieve the communicative competence which covers Discourse Competence, Actional Competence, Linguistic Competence, Sociocultural Competence, Strategic Competence[1].

Lewis [2] states that the highest salaries people have the highest vocabulary in the US. Our people read the vocabulary for communicating and giving information if we don't master the vocabulary we cannot communicative well since vocabulary is a basic competence for supporting the speaking, when we talk about the process of mastering vocabulary, we have to deal with the ways of enriching vocabulary. If the students could master and always 
remember all the vocabulary learned at school when they have graduated their vocabulary of English would be adequate. Different situation speaking is a major achievement in a student language development, and it is considered to be inner ability now she/he communication in his/her life. Therefore, the most important skill which is used for communication is speaking. In daily life, many people express their thought and feeling through speaking.

According to the Content standard of 2006, the greater part of the course is devoted to listening and speaking than reading and writing.In our community, there are people who understandEnglish but they can not speak in English. We must realize that speaking is part of language learning by speaking, not only we communicative to other people but also express our idea, in this matter we can conclude that speaking is an important thing to learn, and vocabulary was one of the most important aspects of foreign language learning.

Some series of studies conducted by scholars deal with the role and impact of vocabulary on language skills especially in speaking. Being good at speaking as one of the language skills, speakers should have not only a good comprehension of knowledge of language features but also the ability to process information and language in context.[3]Speaking makes the student build up their vocabulary. If the students instead concentrate on learning to speak, they can speak. First at that time, they just read pleasure to practice each day. Vocabulary mastery can be done. Whenever and wherever the student meet friends or in their environment. Moreover Vocabulary is recognized as an important component and good indicator of second language performance and proficiency[4].

Moreover, Vocabulary knowledge is often viewed as a critical tool for second language learners because of a limited vocabulary in a second language impedes successful communication. Underscoring the importance of vocabulary acquisition, Schmitt (2000) as cited in [5] emphasizes that lexical knowledge is central to communicative competence and to the acquisition of a second language. Speaking in a foreign language is considered to be a challenging aspect of language learning that demands competence and mastery in learning any foreign language. Vocabulary learning verifies to play an important role in oral communication[6] and Hamad (2013) agrees that vocabulary is a key issue inspeaking performance of Saudi EFL learners.

Based on the notions above, thiswritertried to investigate the research under the title "The correlation of students' of vocabulary mastery and students'speaking skill" at the second grade of MTs Mursyidatul Jannah Pandeglang.

\section{METHOD}

The writer employs correlation study to investigate whether there was any correlation of students' vocabulary mastery and speaking skills. There are thirty participants of the study and vocabulary and speaking tests were administered to collect the data. The data from vocabulary and speaking test were then analyzed by using Person Product-moment formula.

\section{RESULTS}

TABLE I. TESTING CORRELATION

\begin{tabular}{|c|c|c|c|c|c|c|}
\hline $\mathbf{N O}$ & $\mathbf{C O D E}$ & $\mathbf{X}$ & $\mathbf{Y}$ & $\mathbf{X}^{\mathbf{2}}$ & $\mathbf{Y}^{\mathbf{2}}$ & $\mathbf{X Y}$ \\
\hline 1. & AR & 8 & 8 & 64 & 64 & 64 \\
\hline 2. & DU & 5 & 6 & 25 & 36 & 30 \\
\hline 3. & DA & 5 & 5 & 25 & 25 & 25 \\
\hline 4. & EH & 7 & 6 & 49 & 36 & 42 \\
\hline 5. & ES & 4 & 6 & 16 & 36 & 24 \\
\hline 6. & HS & 7 & 8 & 49 & 64 & 56 \\
\hline 7. & HN & 7 & 8 & 49 & 64 & 56 \\
\hline 8. & HM & 7 & 7 & 49 & 49 & 49 \\
\hline 9. & IS & 6 & 7 & 36 & 49 & 42 \\
\hline 10. & IR & 6 & 7 & 36 & 49 & 42 \\
\hline 1. & JA & 7 & 6 & 49 & 36 & 42 \\
\hline 12. & JI & 6 & 6 & 36 & 36 & 36 \\
\hline 13. & KK & 5 & 6 & 25 & 25 & 35 \\
\hline 14. & NA & 8 & 7 & 64 & 49 & 56 \\
\hline 15. & RI & 6 & 7 & 36 & 49 & 42 \\
\hline 16. & AH & 7 & 8 & 49 & 64 & 56 \\
\hline 17. & AS & 6 & 7 & 36 & 49 & 42 \\
\hline 18. & SY & 6 & 7 & 36 & 49 & 42 \\
\hline 19. & SE & 7 & 6 & 49 & 36 & 42 \\
\hline 20. & SM & 6 & 7 & 36 & 49 & 42 \\
\hline 21. & SD & 8 & 7 & 64 & 49 & 56 \\
\hline 22. & SR & 7 & 6 & 49 & 36 & 42 \\
\hline 23. & SH & 6 & 7 & 36 & 49 & 42 \\
\hline 24. & SK & 7 & 8 & 49 & 64 & 56 \\
\hline 25. & ST & 6 & 5 & 36 & 25 & 30 \\
\hline 26. & SS & 6 & 7 & 36 & 49 & 42 \\
\hline 27. & SN & 8 & 7 & 64 & 49 & 56 \\
\hline 28. & VA & 7 & 8 & 49 & 64 & 56 \\
\hline 29. & YS & 6 & 7 & 36 & 49 & 42 \\
\hline 30. & YY & 5 & 6 & 25 & 36 & 30 \\
\hline $\mathbf{N}=\mathbf{3 0}$ & & $\mathbf{\Sigma x}=\mathbf{1 9 2}$ & $\mathbf{\Sigma} \mathbf{y}=\mathbf{2 0 2}$ & $\mathbf{\Sigma} \mathbf{x}^{\mathbf{2}}=\mathbf{1 2 5 8}$ & $\mathbf{\Sigma} \mathbf{y}^{\mathbf{2}}=\mathbf{1 3 8 4}$ & $\mathbf{\Sigma x y = 1 3 0 7}$ \\
\hline & & & & & & \\
\hline
\end{tabular}


Testing the correlation between variable $\mathrm{x}$ and variable $y$ the writer uses Pearson product-moment correlation.

Testing the hypothesis of the correlation, the result of the computation showed that $r$ accounted was 0,54 whereas $\mathrm{r}$-table was 0,46 the writer concluded that $\mathrm{r}$ accounted $>\mathrm{r}$ table, it means that the null hypothesis was rejected.

\section{CONCLUSION}

In this study the writer has only investigated the correlation between student's vocabulary mastery and student's speaking skills, at the second grade of MTs Mursyidatul Jannah is good enough, because the average score of the student vocabulary is 6,5 and the student's speaking skill is 6,7 .

The result of computation and hypothesis testing show that vocabulary mastery and speaking skills. The obtained value of $\mathrm{r}$ is 0,54 the critical value of the Pearson Product Moment coefficient correlation at the level significant of $1 \%$ for the directional test is 0,46 from the result the writer decides that $r$ obtained $(0,54)$ is greater than $r$ critical value $(0,46)$ it means the r-value (the correlation) is significant.

\section{ACKNOWLEDGMENT}

Researchers would like to thank certain parties or people who have supported this research. First, my parents who always pray me everywhere, second STKIP Setia Budhi Rangkasbitung for the internal grant. Third, my friends for the ongoing moral support so that the Researchers arecontinuously engaged in doing the research.

\section{REFERENCES}

[1] Kimtafsirah, Teaching English Communicatively Based on C-BC. Departemen Pendidikan Nasional, 2004.

[2] Agustinus; Ngadiman, "Learning and Remembering Vocabulary," in Proceeding of 59th TEFLIN INTERNATIONAL COMFERENCE, p. p.210.

[3] J. Harmer, The Practice of English Language Teaching. London Longman, 2001.

[4] R. Koizumi and Y. In'nami, "Vocabulary Knowledge and Speaking Proficiency among Second Language Learners from Novice to Intermediate Levels," J. Lang. Teach. Res., vol. 4, no. 5, pp. 900-913, 2013.

[5] M. ALQAHTANI, "The importance of vocabulary in language learning and how to be taught," Int. J. Teach. Educ., vol. III, no. 3, pp. 21-34, 2015.

[6] R. M. I. Khan, N. R. M. Radzuan, M. Shahbaz, A. H. Ibrahim, and G. Mustafa, "The Role of Vocabulary Knowledge in Speaking Development of Saudi EFL Learners," SSRN Electron. J., vol. 9, no. 1, pp. 406-418, 2018

[7] Arikunto Siharsini, Procedure Penelitian Suatu Pendidikan Praktek. PT Rineka Cipta, 2001. 